\title{
ISOLATES OF UREAPLASMA DIVERSUM GENOTYPED BY SINGLE-ENZYME AMPLIFIED LENGTH POLYMORPHISM
}

\author{
Melissa Buzinhani ${ }^{1}$; Elena Mettifogo ${ }^{1}$; Marcos R. Buim ${ }^{1}$; Andréa M. Moreno² ${ }^{2}$ Renata Paixão ${ }^{2}$; Jorge Timenetsky ${ }^{1 *}$ \\ ${ }^{1}$ Instituto de Ciências Biomédicas II, Universidade de São Paulo, Brazil; ${ }^{2}$ Faculdade de Medicina Veterinária e Zootecnia, \\ Universidade de São Paulo, São Paulo, Brazil
}

Submitted: May 19, 2006; Returned to authors for corrections: September 19, 2006; Approved: January 18, 2007

\begin{abstract}
Isolates of Ureaplasma diversum recovered from bovines with reproductive disorders and healthy ones of four premises were compared by SE-AFLP. Twenty-eight SE-AFLP profiles without monomorphic fragments were obtained. The ureaplasma studied were divided in clusters A and B. Cluster A was divided in subclusters $\mathrm{A} 1$ and A2, while A1 was divided in subclusters A1a and A1b. Cluster B grouped only the reference strains. The clusters obtained were not associated with the reproductive disorders. The dendrogram obtained showed high heterogeneity among the studied ureaplasmas and indicated a low genomic stability as detected in other species of microorganisms of class Mollicutes.
\end{abstract}

Key words: Ureaplasma diversum, SE-AFLP, bovine, reproductive disorders

\section{INTRODUCTION}

Roughly 200 species of Mollicutes (mycoplasmas) inhabit humans, animals, insects or plants as comensal, oportunistic or pathogenic agents. These bacteria may cause acute infections, but usually the diseases follow chronic courses (29). Some animal origin mollicutes interfere with the health of commercial species, laboratory animals and domestic animals like cats and dogs (22).

A circular double-stranded DNA is distinguished by the minute size of the mollicute genome and the low $(\mathrm{G}+\mathrm{C})$ content, within a rather narrow range from 24 to $33 \mathrm{~mol} \%$. In addition, these bacteria have a reduced metabolism and present sterols in the cell membrane. Nonetheless, the biologic diversity among species, variants and strains challenges the understanding of their characteristics (7). Methods based on DNA analysis $(3,8,9)$ have shown intra-specific genetic variations in the most important species of genus Mycoplasma $(4,11,15,28)$. This allowed for grouping some field isolates recovered from outbreaks and helped us to identify their origin.

Seven species of genus Ureaplasma are described in some mammals and birds. Ureaplasma may cause severe placentitis, fetal alveolitis, abortion, or birth of weak calves $(18,25)$. This agent was previously considered a non pathogenic species because it was also found in healthy animals. However, the association of $U$. diversum with cattle diseases led to consider this mollicute as a pathogenic species in bovines $(5,6)$.

$U$. diversum has approximately $750 \mathrm{Kpb}$, and the genotypic variations of field isolates are unknown. In the present study, isolates of $U$. diversum recovered mainly from female bovines with or without reproductive disorders were assessed by means of Single-Enzyme Amplified Fragment Length Polymorphism (SEAFLP) (17), a method used to verify genotypic differences among microorganisms. This generated initial groupings of $U$. diversum isolates, which may help to better understand their distribution.

\section{MATERIALAND METHODS}

\section{Ureaplasma strains and culture conditions}

Thirty isolates of $U$. diversum identified by PCR (2) and two type-strains, ATCC 49782 and 49783, were studied. These isolates and strains were cultured and stored at $-70^{\circ} \mathrm{C}$ in Ureaplasma Medium $(25,26)$. The isolates have been recovered from vulvuvaginal mucous of five healthy bovines, 24 females yelding reproductive disorders (abortion, granular vulvitis, infertility) and from semen of one healthy animal. The isolates were recovered between 1999 and 2002. The animals with reproductive disorders

*Corresponding Author. Mailing address: USP - ICB II - Rua Prof. Lineu Prestes, 1374 Cidade Universitária 05508-900 São Paulo, SP - Brasil. Tel.: (11) 3091-7297 ou (11) 3091-7354. E-mail: joti@usp.br 
were from Brazilian farms located in the state of São Paulo (premises I, II and IV). The fourth group was from the state of Mato Grosso (healthy animals from property III). The isolates and the type strains were initially cultured in candle jars at $37^{\circ} \mathrm{C}$ in $1.8 \mathrm{~mL}$ of Ureaplasma Medium supplemented with 5\% CMRL1066 (with glutamine and without bicarbonate - Gibcoß) $(22,23)$.

\section{DNA extraction}

The DNA from the strains was extracted from $50 \mathrm{~mL}$ of each expanded culture. The ureaplasma cells were concentrated by centrifugation at 16,000 $\mathrm{xg}$ for 25 minutes, and DNA extraction was obtained with phenol/chlorophorm (27).

\section{SE-AFLPsubtyping}

An aliquot of $10 \mu \mathrm{l}$ of ureaplasmal DNA $(50 \mathrm{ng} / \mu \mathrm{l})$ was digested overnight ( 18 hours) at $37^{\circ} \mathrm{C}$ with $24 \mathrm{U}$ of HindIII (Life Technologies $($ ) in the buffer of enzyme and water in a volume of $10 \mu \mathrm{l}$. Five microliters of digested DNA was used in a reaction containing $0.2 \mu \mathrm{g}$ of each adapter oligonucleotide - ADH1 - 5', CGGTATGCGACAG 3' and ADH2 - 3' GAGTGCCATACGC TGTCTCGA 5' (17), 1 U of T4 DNA ligase (Life Technologies $®)$, $4 \mu \mathrm{l}$ ligase buffer, and water, in a final volume of $20 \mu \mathrm{l}$ incubated at room temperature for 3 hours. Ligated DNA was heated to $80^{\circ} \mathrm{C}$ for 10 minutes (17).

PCR was performed in $5 \mu \mathrm{L}$ of ligated DNA to generate templates, $2.5 \mathrm{mM} \mathrm{MgCl} 2,300 \mathrm{ng}$ of primer HIG - 5' GGTATGCGACAGAGCTTG 3' (17), 1 U of Taq DNA polymerase in 1x PCR buffer (Life Technologies ${ }^{\circledR}$ ) and completed with ultrapure water to the final volume of $50 \mu \mathrm{l}$.

The mixture was initially denatured at $94^{\circ} \mathrm{C}$ for 4 minutes, followed by 35 cycles at $94^{\circ} \mathrm{C}$ for 1 minute, $60^{\circ} \mathrm{C}$ for 1 minute, and $72^{\circ} \mathrm{C}$ for 2.5 minutes. The procedure was performed twice to confirm reproducibility.

\section{Fragment detection and analysis}

Amplified products $(15 \mu \mathrm{l})$ were electrophoresed in a $2 \%$ agarose gel with ethidium bromide $(0.5 \mathrm{mg} / \mathrm{mL})$ and observed with ultraviolet light. The size of the fragments was measured using the Vilber Lourmat Photodocumentation program (Image Master VDS, Amersham Pharmacia Biotech $\left.{ }^{\circledR}\right)$. A dendrogram was constructed using the NTSYS program (24). The UPGMA method with arithmetic meaning was used to determine the genetic relationship between isolates and strains, applying the Dice similarity coefficient (\%). The discriminatory index of the method was calculated as described by Hunter and Gaston (10).

\section{RESULTS}

The studied isolates generated fragments between $400 \mathrm{bp}$ and 3,000 bp (Fig. 1). Twenty-eight profiles were detected, and no monomorphic bands were observed among the $U$. diversum isolates. The ID calculated for SE-AFLP was 0.98. The reproducibility of the tests yielded differences in the intensity of the bands, but did not lead to differences in the analysis of the groups. A dendrogram (Fig. 2) obtained by the Dice coefficient grouped the ureaplasma isolates in clusters A and B.

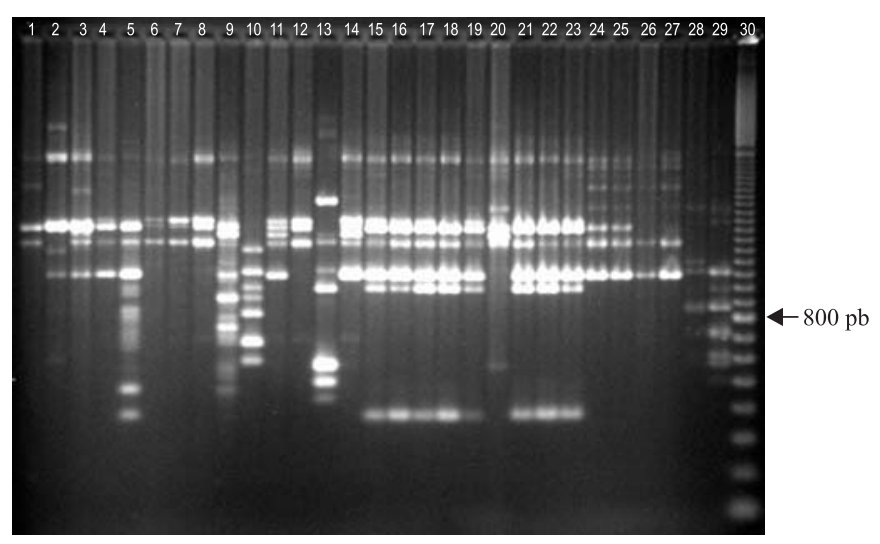

Figure 1. SE-AFLP patterns obtained with primer HI-G of $U$. diversum isolates recovered from bovines from four properties. Lanes 1 to 3: property 1; lanes 4, 5, 15 to 23: property II; lanes 6 to 14 : property IV; lanes 24 to 28 : property III; lanes 29: property IV; lane 30: 100 bp DNA Ladder.

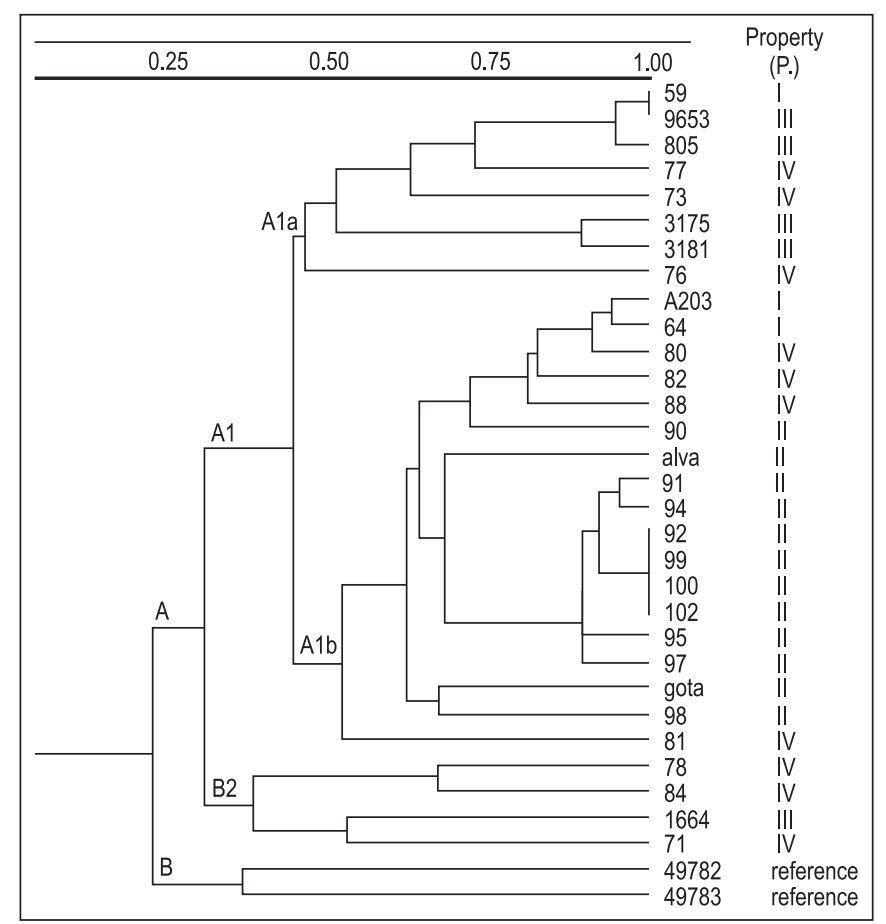

Figure 2. Relation among $U$. diversum isolates on the basis of SE-AFLP patterns. Dendrogram constructed by the use of UPGMA.Percentages of similarity patterns were calculates by Dice's coefficient. 
Cluster A was divided into two subclusters (A1 and A2), and A1 was further divided into other subclusters Ala, A1b. Subcluster A1a grouped eight isolates recovered from animals of farms I, IIII and IV and presented a similarity of about $45 \%$. In subcluster A1b, two isolates from farm I, all isolates of farm II (twelve) and four isolates of farm IV were assembled with a similarity rate over $50 \%$. In subcluster A2, two samples from farm III were grouped with two samples from farm IV, with $40 \%$ of similarity. Cluster B contained only the type strains.

\section{DISCUSSION}

In the present study, SE-AFLP showed high discriminative differentiation among $U$. diversum isolates detecting 28 profiles of 32 isolates, which allowed for grouping these ureaplasmas in two clusters. The $U$. diversum type strains were grouped in cluster B probably because they have another origin; consequently, they did not present similar profiles when compared to the Brazilian genotypes. Subclusters A1a and A2 presented large genotype diversity, being obtained from healthy and sick animals from different farms. The sub cluster A $1 \mathrm{~b}$ also presented a high genetic heterogeneity among 18 isolates recovered from animals with reproductive disorders. In addition, twelve $(66.60 \%)$ isolates were from farm II, and the DNA fragments studied are more homogeneous compared with isolates obtained from other farms. The isolates from farm II were recovered during an acute outbreak of the disease, suggesting a recent introduction or a brief presence of microorganism in farm II, not allowing for DNA modification. The ureaplasmal heterogeneity in the same herd may be justified by the introduction of new specimens due to their frequent transportation and commerce from Brazilian farms.

Spontaneous mutations in isolates of $M$. hyosynoviae recovered from swine were suggested when this host remained for prolonged periods in the same herd (13). In contrast, isolates of M. mycoides spp mycoides recovered from cattle in Tanzania (16) and in isolates of M. bovis recovered in Denmark (15) presented a genomic stability, allow for establishing an epidemiological relationship. Isolates of M. capricolum subsp. capripneumoniae were analyzed by means of AFLP, providing 13 different profiles of 38 isolates (12). Other genotypic variations were detected in other species of genus Mycoplasma $(11-14,16,21)$. The pathogenicity or the epidemiologic relationship of the genomic diversity in the isolates studied has not been established yet. The results presented are the initial parameters for the genomic comparison of $U$. diversum field isolates by the use of SE-AFLP.

Genotypic variation may be related to the frequency of repetitive elements or insertion of sequence elements in the Mollicute genome (23). These sequences may provide an attractive substrate for recombinational deletion of large genomic regions during mycoplasma evolution, consistent with the genetic plasticity associated with the high frequency antigenic variation common in this microbial class (1). Intra-species variability of genome size may be caused by integration of viral sequences into mycoplasmal chromosome, as mentioned in Spiroplasma citri (1).

The methodology used supports the comparison of intraspecies diversity of ureaplasma. $U$. diversum usually presents fast growth in the prime isolation; however, it is more difficult to subculture some isolates and extract the respective DNA. The SE-AFLP requires a small amount of DNA; less expensive equipment than Pulsed Field Gel Electrophoresis (PFGE); does not require Southern-blotting followed by probing; is simple to perform and more reproducible than Random Amplified Polymorphic DNA methodology (RAPD) $(19,20)$.

The detected heterogeneity of studied $U$. diversum isolates suggests a low genomic stability and complies with the evolution of Mollicutes (30). Additional studies are needed on the distribution of this ureaplasma in bovine herds to better associate the isolates, the diseases and their frequencies to further understand and control this microorganism.

\section{ACKNOWLEDGMENTS}

This work was supported by FAPESP, process: 01/09835-0.

\section{RESUMO}

\section{Tipagem genotípica de estirpes de Ureaplasma diversum por meio da amplificação de fragmentos polimórficos com única enzima (SE-AFLP)}

Cepas de referência e 30 estirpes de Ureaplasma diversum isoladas do muco vaginal de bovinos apresentando ou não distúrbios reprodutivos, de quatro diferentes propriedades, foram comparadas por meio da metodologia da SE-AFLP (single-enzyme amplified fragment length polymorphism). Foram obtidos 28 perfis, com ausência de fragmentos monomórficos. No dendrograma, as amostras foram divididas em grupos A e B. O grupo A foi subdividido em A1 e A2 e o A1 dividiu-se em A1a e A1b. As amostras de referência formaram o grupo B. Não houve diferenciação entre as estirpes isoladas de animais doentes ou sadios. Evidenciou-se grande heterogeneidade entre os ureaplasmas estudados indicando baixa estabilidade genômica, como detectado em outras espécies dos microrganismos da classe Mollicutes.

Palavras-chave: Ureaplasma diversum, SE-AFLP, bovino, distúrbios reprodutivos

\section{REFERENCES}

1. Bebear, C.M.; Aullo, P.; Bove, J.M.; Renaudin, J. (1996). Spiroplasma citri virus $\mathrm{SpV} 1$ : characterization of viral sequences present in the spiroplasmal host chromosome. Curr. Microbiol., 32, 134-140. 
2. Buzinhani, M. (2001). Dissertation (mestrado). Universidade de São Paulo, São Paulo. Detection of micoplasmas by culture and polymerase chain reaction from bovine female with reproductive disturbances.

3. Cousin-Allery, A.; Charron, A.; de Barbeyrac, B.; Fremy, G.; Skov Jensen, J.; Renaudin, H.; Bébéar, C. (2000). Molecular typing of Mycoplasma pneumoniae strains by PCR-based methods and pulsedfield gel electrophoresis. Application to French and Danish isolates. Epidemiol. Infect., 124(1), 103-111.

4. Cristiensen, G.; Andersen, H. (1988). Heterogeneity among Mycoplasma hominis strains as detected by probes containing parts of ribosomal ribonucleic acids genes. Int. J. Syst. Bacteriol., 38, 108115 .

5. Doig, P.A.; Ruhnke, H.L.; Palmer, N.C. (1980a). Experimental bovine genital ureaplasmosis: I. Granular vulvitis following vulvar inoculation. Can. J. Comp. Med., v.44, p.252-258.

6. Doig, P.A.; Ruhnke, H.L.; Palmer, N.C. (1980b). Experimental bovine genital ureaplasmosis: II. Granular vulvitis, endometritis and salpingitis following uterine inoculation. Can. J. Comp. Med., v.44, p. 259-266.

7. Dybvig, K.; Voelker, L. (1996). Molecular Biology of Mycoplasmas. Ann. Rev. Microbiol., 50, 25-57.

8. Frey, J.; Haldimann, A.; Nicolet, J. (1992). Chromosomal heterogeneity of various Mycoplasma hyopneumoniae field isolates. Int. J. Syst. Bacteriol., 42, 275-280.

9. Geary, S.J.; Forsyth, M.H.; Aboul Saoud, S.; Wang, G.; Berg, D.E.; Berg, C.M. (1994). Mycoplasma gallisepticum strain differentiation by arbitrary primer PCR (RAPD) fingerprinting. Mol. Cell. Probes, 8, 311-316.

10. Hunter, P.R.; Gaston, M.A. (1998). Numerical index of the discriminatory ability of typing systems: an application of Simpson's index of diversity. J. Clin. Microbiol., 26: 2465-2466.

11. Kokotovic, B.; Friis, N.F.; Jensen, J.S.; Ahrens, P. (1999). Amplifiedfragment length polymorphism fingerprinting of Mycoplasma species. J. Clin. Microbiol., 37(10), 3300-3307.

12. Kokotovic, B.; Bolske, G.; Ahrens, P.; Johasson, K.E. (2000). Genomic variations of Mycoplasma capricolum subsp. capripneumoniae detected by amplified fragment length polymorphism (AFLP) analysis. FEMS Microbiol. Lett., 184, 6368.

13. Kokotovic, B.; Friis, N.F.; Nielsen, E.O.; Ahrens, P. (2002a). Genomic diversity among Danish field strains of Mycoplasma hyosynoviae assessed by amplified fragment length polymorphism analysis. Vet. Microbiol., 85, 221-231

14. Kokotovic, B.; Friis, N.F.; Ahrens, P. (2002b). Characterization of Mycoplasma hyosynoviae strains by amplified fragment length polymorphism analysis, pulsed-field gel electrophoresis and $16 \mathrm{~S}$ ribosomal DNA sequencing. J. Vet. Med., B 49, 245-252.

15. Kusiluka, L.J.M.; Kokotovic, B.; Ojeniyi, B.; Friis, N.F.; Ahrens, P. (2000). Genetic variations among Mycoplasma bovis strains isolated form Danish cattle. FEMS Microbiol. Lett., 192, 113-118.
16. Kusiluka, L.J.M.; Ojeniyi, B.; Friis, N.F.; Kokotovic, B.; Ahrens, P. (2001). Molecular epidemiology of Contagious Bovine Pleuropneumonia in Tanzania based on amplified fragment length polymorphism and pulsed-field gel electrophoresis analysis. J. Vet. Med. B, 48, 303-312.

17. McLuchlin, J.; Ripabelli, G.; Brett, M.M.; Threlfall, E.J. (2000). Amplified fragment length polymorphism (AFLP) analysis of Clostridium perfringens for epidemiological typing. Int. J. Food Microbiol., 56, 21-28.

18. Miller, R.B.; Ruhnke, H.L.; Doig, P.A.; Poitras, B.J.; Palmer, N.C. (1983). The effects of Ureaplasma diversum inoculated into the dynamic cavity in cows. Theriogenology, 20, 367-373.

19. Moreno, A.M.; Baccaro, M.R.; Ferreira, A.J.P.; Pestana de Castro, A.F. (2003). Use of single-enzyme amplified fragment length polymorphism for typing Pasteurella multocida subsp. multocida isolates from pigs. J. Clin. Microbiol., 41(4), 1743-1746.

20. Olive, M.D.; Bean, P. (1999). Principles and applications of methods for DNA-based typing of microbial organism. J. Clin. Microbiol., 37(6), 1661-1669, 1999.

21. Poumarat, F.; Solsona, M. Molecular epidemiology of Mycoplasma mycoides subsp. Mycoides biotype small colony the agent of contagious bovine pleuropneumoniae. Vet. Microbiol., 47, 305-315.

22. Razin, S.; Barile, M.F. (1985). Mycoplasma pathogenicity. In: Razin, S.; Barile, M.F. (eds). The mycoplasmas. Academic Press, Orlando, v.4.

23. Razin, S.; Yogev, D.; Naot, Y. (1998). Molecular Biology and Pathogenicity of Mycoplasmas. Microbiol. Mol. Biol. Rev., 10941156.

24. Rohlf, F.J. (1992). Program Numerical taxonomy and multivariate analysis system. Version 1.70, New York.

25. Ruhnke, H.L. (1984). Mycoplasmas associated with bovine genital tracts infections, In: Whitford, H. W.; Rosenbusch, R.F.; Lauerman, L.H. (eds). Mycoplasmosis in Animals: Laboratory Diagnosis. Iowa State University Press, Ames, Iowa, p.56-62.

26. Ruhnke, H.L.; Rosendal, S. (1994). Useful protocols for diagnosis of animal mycoplasmas. In: Whitford, H.W.; Rosenbusch, R.F.; Lauerman, L.H. (eds). Mycoplasmosis in Animals: Laboratory Diagnosis. Iowa State University Press, Ames, Iowa, p.141-144.

27. Sambrook, J.; Fritsch, E.F.; Maniats, T. (1989). Analysis and cloning of eukaryotic genomic DNA. In: Sambrook, J.; Fritsch, E.F.; Maniats T. (eds). Molecular Cloning: A Laboratory Manual. Cold Spring Harbor Laboratory Press, p.9.16-9.19.

28. Tola, S.; Idini, G.; Rocchigiani, A.M.; Manunta, D.; Angioi, P.P.; Rocca, S.; Cocco, M.; Leori, G. (1999). Comparison of restriction pattern polymorphism of Mycoplasma agalactiae and Mycoplasma bovis by pulsed field gel electrophoresis. Zentralbl. Veterinarmed B., 46(3), 199-206.

29. Tully, J.G. (1993). Current status of the mollicute flora human. Clin. Infect. Dis., v.17, p.S2-S9.

30. Woese, C.R. (1987). Bacterial evolution. Microbiol. Rev., 51(2), 221-71. 